\title{
A phyto-pharmacological overview on Jewel Weed
}

\author{
Khyati Narendrakumar Shah ${ }^{1 *}$, Preeti Verma ${ }^{2}$, Bhanubhai Suhagia ${ }^{3}$ \\ ${ }^{1}$ B. K. Mody Govt. Pharmacy College, Rajkot, India. \\ ${ }^{2}$ L. M. College of Pharmacy, Ahmedabad, India. \\ ${ }^{3}$ Faculty of Pharmacy, Dharamsinh Desai University, Nadiad, India.
}

\section{ARTICLE INFO \\ Article history: \\ Received on: 03/01/2017 \\ Accepted on: 05/03/2017 \\ Available online: 30/08/2017}

Key words:

Jewel weed, Impatiens

balsamina, Balsaminaceae,

Garden plant, phytochemical

constituents.

\begin{abstract}
Jewel weed is a common name of Impatiens balsamina Linn. (Family, Balsaminaceae). It is often grown as garden plant due to its attractive foliage and flowers. It is traditionally used as diuretic, emetic, laxative, demulcent and tonic. It is reported to possess beneficial effects in lumbago, intercostal neuralgia and in burns. Studies have revealed presence of various phytoconstituents like flavanoids, triterpenoids, glycosides, fatty acids and alkaloids. The present review is an attempt to summarize traditional values, pharmacognostical and phytopharmacological reports of Jewel weed.
\end{abstract}

\section{INTRODUCTION}

Jewel weed, scientifically known as Impatiens balsamina Linn. (Syn. Balsamina hortensis) belonging to family Balsaminaceae, is an annual, erect herb having 30-90 cm height (Herber, 1864) (Fig. 1). It is distributed throughout India, Ceylon (up to $5000 \mathrm{ft}$ height), China and Malaya. In India it is commonly cultivated as garden plant throughout tropical and sub-tropical parts, grows gregariously as forest under growth and commonly seen on the boarders of rice fields (Chatterjee and Pakrashi, 1997; Collett, 1921). It may be found in large patches on damp ground and also in small clumps along the road sides (Madhav, 1959). Whole plants and flowers are used for medicinal and cosmetic purpose. In India it is known by various

* Corresponding Author

Email: khyati_ns @yahoo.co.in vernacular names: Dushpatrijati (Sanskrit); Gulmendhi (Hindi); Dupati (Bengali); Kasittumbai (Tamil); Jewel Weed, Garden Balsam, Balsam Weed, Touch-me-not (English); Terada (Marathi); Gulmendi, Tanmania (Gujarati); Tambol, Bontil (Punjabi); Haragaura (Oriya) and Mecchingom (Malayalam). (Anonymous, 1959; Kirtikar and Basu, 1933; Nadkarni, 1989; Chopra et al., 1969).

\section{TAXONOMICAL CLASSIFICATION}

$\begin{array}{lll}\text { Kingdom } & : & \text { Plantae } \\ \text { Division } & : & \text { Spermatophyta } \\ \text { Subdivision } & : & \text { Angiospermae } \\ \text { Class } & : & \text { Dicotyledonae } \\ \text { Subclass } & : & \text { Asteridae } \\ \text { Order } & : & \text { Ericales } \\ \text { Family } & : & \text { Balsaminaceae } \\ \text { Genus } & : & \text { Impatiens } \\ \text { Species } & : & \text { balsamina }\end{array}$




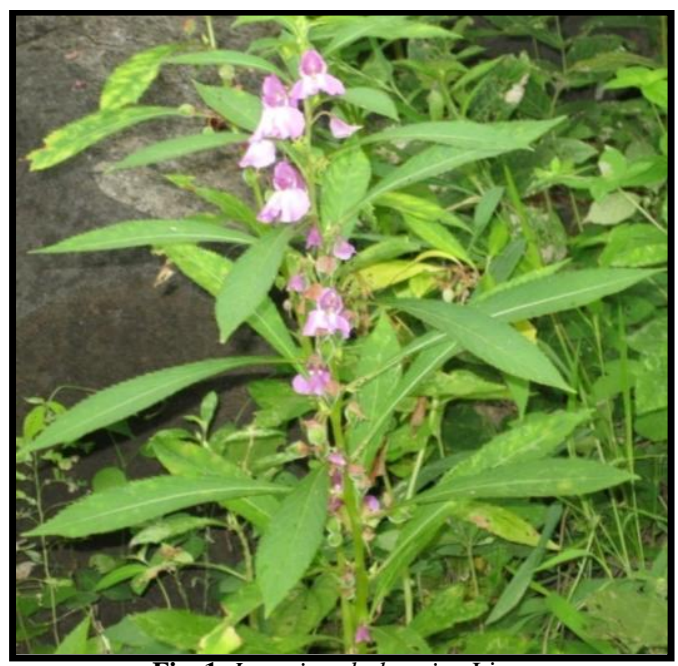

Fig. 1: Impatiens balsamina Linn.<smiles>O=c1c(O)c(-c2ccc(O)cc2)oc2cc(O)cc(O)c12</smiles>

Kaempferol<smiles>O=C1C=C(O)C(=O)c2ccccc21</smiles>

Lawsone<smiles>COC1=CC(=O)c2ccccc2C1=O</smiles>

Lawsone methyl ether<smiles>CC(CO)C1CC[C@]2(CC[C@@]3(C)C(CC[C@]4(C)[C@@]3(C)CC[C@]3(C)[C@@](C)(CO)[C@@H](O)CC[C@@]34C)[C@@H]2O)OC1</smiles>

Hosenkol A<smiles>O=C1C(O)=C(CC2=C(O)C(=O)c3ccccc3C2=O)C(=O)c2ccccc21</smiles>

Methylene-3,3'-bilawsone

Fig. 2: Chemical constituents of Impatiens balsamina Linn.

\section{Botanical Description}

It is a pubescent or glabrate, erect, branched succulent annual herb. Young shoots are hairy. Stem bears alternate, up to 15 $\mathrm{cm}$ long, narrowly lanceolate, acuminate, deeply serrate, glabrous leaves which bear decurrent, shot, pubescent petiole. Flowers are rose coloured or nearly white, axillary, pubescent, slender and shorter than the leaves. Fruits are capsular, tomentose and hairy, with rigid yellow bristles, ellipsoid and narrowed at both ends. Seeds are globose, tubercled, $0.5 \mathrm{~cm}$ in diameter, reticulate and having black testa. Flowers and fruits appear during rainy season (Chatterjee and Pakrashi, 1997; Kirtikar and Basu, 1933).

\section{Traditional Uses}

The plant and its parts are widely used by tribal people for curing variety of ailments. The medicinal uses of I. balsamina are also mentioned in ancient books. Whole plant is having emetic, diuretic and laxative properties when taken internally and externally it is used for pains in joints (Chopra et al., 1956; Jaykrishna, 1998).

The flowers are having cooling, demulcent and tonic effect and applied in case of burns and scalds. They are also used for lumbago and intercostals neuralgia (where they are reported to relieve stasis and improve circulation). Leaves are used in poultices in Philippines and seeds are said to be beneficial for difficult labour in China. In Bali, leaves are eaten and flowers and leaves are used for dyeing finger nails (as substitute of henna i.e. Lawsonia inermis Linn.) (Anonymous, 1959).

In Madhya Pradesh, ethnomedicinally the plant is used for the treatment of inflammation, burns, ulcers, constipation, arthritis and urinary retention (by tribal people) in Amarkantak region and root extract is used for treatment of irritation of gastrointestinal canal in Pachmarhi region (Srivastava et al., 2012; 
Mishra et al., 2012). In Garhwal Himalaya, Uttaranchal, leaf paste is externally applied in burns, where the plant is known as Balsam or Majethi in local regions (Uniyal and Shiva, 2005). Leaves of $I$. balsamina (Local name: Keembung) are pounded and applied topically to treat split nails in some villages of Malaysia (Ong et al., 2011). It is also believed to be a useful cosmetic herb (Sanghi and Tiwle, 2013). Ethnomedicinally the flowers are utilized in cases of snake bites (Binorkar and Jani, 2012). The aerial parts of plant are used for treatment of articular rheumatism, bruises and beriberi in Chinese herbal medicine. In some areas of Japan several types of dermatitis, including urticaria, is treated by topical application of squeezed juice of the petals (Chang S, 1977).

\section{PHYTOCHEMISTRY}

Various phytoconstituents have been identified and isolated from various parts of plant including fatty acids, flavanoids, triterpenoids and glycosides.

Flowers of Impatiens balsamina shows presence of flavanol, kampherol (4',5,7-trihydroxyflavonol), quercetin (3', 4',5,7-tetrahydroxyflavonol) and myricetin (3',4',5',5,7pentahydroxyflavonol). Kampherol and myricetin is found in petals and sepals while quercetin is found in sepals only (Clevenger S, 1958). Kaempferol 3-rhamnosyldiglucoside was isolated from white petals of plant and based on spectroscopic techniques its structure was determined to be kaempferol-3-O-[2"O- $\alpha$-L-rhamnopyranosyl-3"O- $\beta$-D-glucopyranosyl]- $\beta$-D-

glucopyranoside (Fukumoto et al., 1994).

Kaempferol, kaempferol 3-glucoside, kaempferol 3glucosylrhamnoside, kaempferol 3-rutinoside and kaempferol 3(p-coumaroyl) glucoside was reported to be present in the plant (Calderon JM, 2011). These naturally occurring structurally similar kaempferol and its derivatives were detected and quantified using capillary electrophoresis with electrochemical detection (Hua et al., 2001).

Determination of total flavonoid and total phenolic content of stem and leaf of Impatiens balsamina, harvested at different time interval (March, May and July) revel that the leaf extracts have higher total flavonoids and total phenolic content than those of stem extracts. More over as the harvest time delayed phenolic contents of stems were significantly decreased but the total phenolic and total flavonoid contents of leaves were significantly increased (Kang et al., 2013).

2-Methoxynaphthalene-1,4-dione $\left(\mathrm{C}_{11} \mathrm{H}_{8} \mathrm{O}_{3}\right)$ (Jin et al., 2011) and 2-Methoxy-1,4-napthoquinone was isolated from leaves of Impatiens balsamina (Kang and Moon, 1992). A Reversedphase High-performance Liquid Chromatography method has been developed and validated for simultaneous determination of three Naphthoquinones i.e. lawsone, lawsone methyl ether and methylene-3,3'-bilawsone; the main active compounds of Impatiens balsamina leaves (Sakunphueak and Panichayupakaranant, 2010). High-Performance Thin-Layer Chromatography method has been developed and validated for quantification of same three napthaquinones using N-butyl acetate- chloroform-glacial acetic acid (6:4:0.1) as mobile phase (Abhijeet et al., 2014).

Two new tetrahydronaphthalenes $1 \alpha, 2 \alpha$-diol-4 $\alpha$-ethoxy1, 2, 3, 4-tetrahydronaphthalene and $1 \alpha, 2 \alpha, 4 \beta$-triol-1, 2, 3, 4tetrahydronaphthalene were isolated from the stem of Impatiens balsamina and their structures were elucidated by various spectroscopic methods (Chen et al., 2010).

Ethanolic extract of dried seeds shows presence of alkaloids, flavanoids, terpenoids, saponins and tannins. The first baccharane triterpenoid from natural source, Hosenkol-A, was isolated from the seeds of Impatiens balsamina and characterized as $\quad(3 \mathrm{~s}, 4 \mathrm{R}, 17 \mathrm{R}, 20 \mathrm{~S}, 24 \mathrm{~S}, 25 \mathrm{~S})-3,17,26,28$-tetrahydroxy-21,24epoxybaccharane (Shoji et al., 1983). New baccharane glycosidesHosenkosides A-E and L-O were isolated from seed and their structures were determined using 2D NMR technique and chemical derivatization (Shoji et al., 1994(a); Shoji et al., 1994(b)). A new monoglyceride - (-)(R,Z)glycerol-1-octadec-9enoate - isolated and characterised from seeds (Patra and Chaudhari, 1988). Seeds also contain $\beta$-sitosterol, a new anthraquinone and palmitic acid, stearic acid, oleic acids as well as their ethyl ester (Rastogi, 1970; Rastogi, 1985; Rastogi, 1990). From the seeds of Impatiens balsamina two flavones glycosides $\mathrm{i}$. e. quercetin-3-O-[ $\alpha$-]-rhamnose- $(1 \rightarrow 2)-\beta$-d-glucopyranosyl]-5-O$\beta$-d-glucopyranoside and quercetin-3-O-[(6",'-O-caffeoyl)- $\alpha$ - $]$ rhamnose-( $1 \rightarrow 2)$ - $\beta$-d-glucopyranosyl]-5-O- $\beta$-d-glucopyranoside were isolated and identified based on various spectral studies (Jing et al., 2010).

Balsaminones A and B (Dinapthofuran-7,12-dione derivatives) were isolated from the pericarp of Impatiens balsamina, together with 2-methoxy-1,4-naphtoquinone, compounds having significant antipruritic activity (Ishiguro et al., 1998).

p-Hydroxybenzoic acid was identified as a precursor of 2-Hydroxy 1,4-Napthoquinone in Impatiens balsamina (Bohm BA, 1967).

A novel natural bisnaphthoquinone, methylene-3,3'bilawsone was isolated from root culture of Impatiens balsamina along with lawsone and 2-methoxy-1,4-naphthoquinone (naphthoquinones); scopoletin and isofraxidin (coumarin) and spinasterol (sterol) (Panichayupakaranant et al., 1995). A new biscoumarin, 4,4'-biisofraxidin has been isolated from the root cultures of Impatiens balsamina, whose structure was elucidated by 1D and 2D NMR techniques (Panichayupakaranant et al., 1998).

\section{PHARMACOLOGICAL ACTIVITIES}

\section{Antibacterial and antifungal}

Various extracts from the plant Impatiens balsamina were screened for the antibacterial activitity against bacterial pathogen like Shigella boydii, Salmonella paratyphii, Proteus vulgaris, Staphylococcus aureus and Cryptococcus neoformans and fungal pathogen like Candida albicans. High zone of inhibition was observed in all tested pathogen except Salmonella 
paratyphii and Proteus vulgaris. These two pathogen shows moderate zone of inhibition (John et al., 2013).

Antimicrobial activity of ethanolic extract of stem and leaf of the plant, harvested at different time interval (March, May and July), on various pathogen revealed that leaf extracts shows marked higher antimicrobial activity than the stem extracts at the same concentration. Ethanol leaf extract, regardless of harvest time, showed strong activity against Candida albicans and Clostridium perfringens; clear activity against Vibrio parahaemolyticus and Bacillus cereus and moderate activity against Salmonella typhimurium and Escherichia coli; slight activity against Staphylococcus aureus and Listeria monocytogenes. Stem ethanolic extract did not show any activity except stem of july harvested sample which is active against Candida albicans and Escherichia coli (Kang et al., 2013).

The three naphthoquinones from the leaf extract of Impatiens balsamina i.e. lawsone, lawsone methyl ether and methylene-3,3'-bilawsone were evaluated for antimicrobial activity against dermatophyte fungi, yeast, aerobic bacteria and facultative anaerobic bacteria. Out of three lawsone methyl ether was found to be most potent and broad spectrum antimicrobial agent (Sakunphueak et al., 2012).

Impatiens balsamina leaves extract in $100 \%, 50 \%$ and $25 \%$ concentration are as effective as $2 \%$ Ketoconazole to inhibit the growth of Candida. Various extracts (alcohol, benzene, chloroform, methane, petroleum ether, cool water and hot water) from the leaf and root of Impatiens balsamina were studied for in vitro antimicrobial activity against 7 bacterial species and 5 fungal species. Excellent antimicrobial activity was found in ethanolic and chloroform extracts against all test microorganism (Rajendra et al., 2014).

A single bioactive compound was isolated from 95\% ethanolic extract of the dried aerial parts of Impatiens balsamina, and identified as 2-methoxy-1,4-naphthoquinone,whose structure was confirmed by various spectroscopic methods. Out of 12 bacterial and 8 fungal strains tested, it was found to have antimicrobial activity against 5 gram-positive and 2 gram-negative strains and all fungai (including multi-drug resistant strains) (Yang et al., 2001).

Isolated kaempferol and quercetin from the flowers of Impatiens balsamina showed antibacterial activity against Propionibacterium acnes and Minimum Inhibitory Concentration (MICs) for both compounds were $\leq 32 \mu \mathrm{g} / \mathrm{ml}$ and $\leq 64 \mu \mathrm{g} / \mathrm{ml}$ for clindamycin-sensitive and resistant $P$. acnes, respectively. Further kaempferol and quercetin separately in combination with clindamycin showed a greater synergic effect than their combination with erythromycin (Lim et al., 2007).

Various extracts of seed of the plant screened by Disc diffusion method showed potential antibacterial action against Bacillus anthracis and Escherichia coli and antifungal action against Aspergillus niger and Fusarium sp. (Jain B, 2011).

The four closely related, plant derived, smallest (20 amino acids long), antimicrobial peptides were isolated from seeds of Impatiens balsamina, designated Ib-AMP1, Ib-AMP2, Ib-
AMP3 and Ib-AMP4. Peptides were inhibitory to the fungai and bacterial growth and were no cytotoxic to cultured human cells (Tailor et al., 1997). Further synthetic variant of Ib-AMP1 was found to be fully active on yeast and fungal strains. Replacement of amino acid residues by arginine or tryptophan, the fungal growth inhibition nor salt-dependency of Ib-AMP4 could be improved by more than two fold (Theyissen et al., 2005). The nonessentialness of disulfide bonds of Ib-AMP1 was proved by synthesizing a disulfide-removed linear analog of Ib-AMP1 which showed 3.7-4.8 fold higher antimicrobial specificity than wild-type Ib-AMP1 (Wang et al., 2009).

\section{Antiinflammatory, analgesic and antidiabetic activity}

The aqueous extract of Impatiens balsamina leaves has been reported to posses analgesic and anti-inflammatory activities (Debashree et al., 2013). The two new 1,4-naphthoquinone sodium salts isolated from the corolla of Impatiens balsamina showed significant selective cyclooxygenase-2 inhibitory activities, which supports the drug to be used to treat articular rheumatism, pain and swelling (Oku and Ishiguro, 2002). Methanol extract of Impatiens balsamina flowers showed strong and dose-dependent antinociceptive activity in chemical and heat induced mice models (Imam et al., 2012).

In vitro antidiabetic and anti-inflammatory activities of ethanolic seed extract were performed by inhibition of alpha amylase enzyme and bovilne serum albumin (BSA) denaturation assay respectively. The results showed that the seeds of the plant have antidiabetic and anti-inflammatory activity which supports the traditional use of the plant (Shivaji et al., 2013).

\section{Anti-anaphylactic activity}

Study of 35\% ethanolic extract of white petals of Impatiens balsamina showed it had a significant anti-anaphylactic activity (Iahiguro et al., 1992). In another study of antianaphylactic effects of an ethanol extract of Impatiens balsamina, kaempferol 3-rutinoside and lawsone from Impatiens balsamina significantly inhibited the decrease of blood flow (Ishiguro et al., 2002).

Due to presence of platelet activating factor antagonist and compound with weak antihistamine effect, in flower extract of Impatiens balsamina, it shows protective effect against severe hypotension resulting from simulated anaphylaxis in mice. (Oku and Ishiguro, 1999; Ishiguro and Fukumoto, 1997).

\section{Antipruritic/Antidermatitic activity}

The balsaminones A and B from the pericarp of the Impatiens balsamina have significant antipruritic activity (Ishiguro et al., 1998).

$100 \mathrm{mg} / \mathrm{kg}, 35 \%$ ethanol extract from petals of Impatiens balsamina was studied in atopic dermatitis model NC mice and found to be effective for the prevention and treatment of atopic dermatitis. Kaempferol 3-rutinoside and 2-hydroxy-1,4naphthoquinone (lawsone) isolated from the extract suppressed scratching behaviour and dermatitis at $10 \mathrm{microg} / \mathrm{kg}$ dose (Oku 
and Ishiguro, 2001). The isolated Kaempferol from the flowers of Impatiens balsamina showed inhibitory activity against mushroom tyrosinase. It also strongly inhibit melanin production by Streptomyces bikiniensis in a dose dependent manner, without inhibiting cell growth (Lim, 2006).

\section{Anti H-Pylori activity}

Extracts of all parts of Impatiens balsamina (including root, stem, leaf, seed and pod) shows bactericidal activity against Helicobacter pylori. The pod extract was more effective, showing lower MIC and MBC (1.25-2.5 and 1.25-5.0 $\mu \mathrm{g} / \mathrm{ml}$, respectively). The acetone and ethyl acetate pod extracts indicate significant activity. This activity exceeded that of metronidazole and approximated to that of amoxicillin (Wang, 2009). Compounds isolated from Impatiens balsamina (2-methoxy-1, 4naphthoquinone (1) and stigmasta-7,22-diene-3 $\beta$-ol (2)) were evaluated for their anti-H. pylori activity. The MICs and MBCs for (1) were $0.156-0.625$ and $0.313-0.625 \mu \mathrm{g} / \mathrm{ml}$, respectively, and they were $20-80 \mu \mathrm{g} / \mathrm{ml}$ for both of MICs and MBCs for (2) against H. pylori resistant to antibiotics (clarithromycin, metronidazole and levofloxacin). The activity of compound (1) was equivalent to that of amoxicillin (Wang et al., 2009).

\section{Anti-androgen effect}

The bisnaphthaquinone derivative named impatienol (1), 3-hydroxy-2-[3-hydroxy-1,4-dioxo (2-naphthyl)] ethyl naphthalene-1,4-dione in the active fraction of $35 \%$ ethanol extract of I. balsamina aerial parts, showed remarkable testosterone 5alpha-reductase inhibitory activity (Ishiguro et al., 2000).

\section{Antioxidant activity}

The antioxidant activities of ethanolic seed extract was determined by reducing power assay (Iron (III) to iron (II) reduction), Phospho molybdenum assay and DPPH free radical scavenging assay. The extract exhibited a high level of free radical scavenging activity (Shiaji et al., 2013). The ethanolic extract of whole plant of Impatiens balsamina showed invivo antioxidant activity, at a concentration of $200 \mathrm{mg} / \mathrm{kg}$ body wt, evaluated by chromium induced oxidative stress in male albino rats (Baskar et $a l ., 2012 \mathrm{a})$. The infusion of plant was evaluated for determination of antioxidant capacities using ferric-reducing antioxidant power $(49.23 \pm 1.07 \mu \mathrm{mol} \mathrm{Fe}(\mathrm{II}) / \mathrm{g})$ and Trolox equivalent antioxidant capacity $(47.36 \pm 2.55 \mu \mathrm{mol}$ Trolox(II)/g) assays, and total phenolic content was measured by Folin-Ciocalteu method( $4.47 \pm$ $0.11 \mathrm{mg} \mathrm{GAE} / \mathrm{g}$ ) (Sha et al., 2013). In another study the aqueous extract of flower of Impatiens balsamina were evaluated for antioxidant capacity by 1,1-diphenyl-2-picrylhydrazyl (DPPH) radical scavenging property and total antioxidant capacity (TAC) and results were obtained $1140.36(\mu \mathrm{g} / \mathrm{ml})$ and 13.04 (AAE) respectively (Archana and Bratati, 2014).

\section{Anthelmintic activity}

Seed oil of Impatiens balsamina (10,50 and $100 \mathrm{mg} / \mathrm{ml})$, exhibit significant anthelmintic activity in terms of time of paralysis and time of death of Pheritima posthuma (Jalalpure et al., 2007).

\section{Anti tumor activity}

The ethanol and chloroform extracts of Impatiens balsamina leaves have shown in vitro anti-tumor activity against the human hepatocellular carcinoma cell line HepG2. Further separation and purification leads to the isolation of active component which was identified as 2-methoxy-1,4naphthoquinone (Ding et al., 2008). Crude leaf extract of Impatiens balsamina leaves and isolated 2-methoxy-1,4naphthoquinone showed histoprotective effects on the pancreas, stomach, duodenum and spleen of tumor-induced mice (Herrera et al., 2013). In another study the ethanol extract of Impatiens balsamina was investigated for in vitro cytotoxicity and in-vivo antitumor activity by Hela and NIH3T3 cells by MTT assay and Dalton's ascites lymphoma tumor bearing mice respectively, where by at 200 and $400 \mathrm{mg} / \mathrm{kg}$ dose, it significantly increase the life span, decrease in the cancer cell number and exert protective effect on the hemopoietic system. The results clearly indicate significant antitumor and cytotoxic effects, which supports ethnomedical use of Impatiens balsamina in cancer therapy (Baskar et al., 2012b). A new dinaphthofuran-7,12-dione derivative named Balsaminone $\mathrm{C}$, isolated from seeds of Impatiens balsamina exhibit cytotoxicity against cancer cell lines A549, Bel-7402 and Hela (Pei et al., 2012). The study was conducted to investigate the cytotoxicity of 2-methoxy-1,4-naphthoquinone against gastric adenocarcinoma (MKN45 cell line). The compound resulted in serious necrosis at dose higher than $50 \mu \mathrm{M}$, via superoxide anion catastrophe (Wang and Lin, 2012).

\section{CONCLUSION}

Plants are being used as curative agents for variety of ailments. Detailed literature survey of the Impatiens balsamina revealed its traditional and medicinal usefulness. Various pharmacological studies reports are available which validate its traditional uses. A number of photochemicals isolated from various parts of plants have shown a variety of activities. However to explore full therapeutic potential of plant, further phytochemical, pharmacological and clinical research is required.

\section{Financial support and sponsorship: Nil.}

Conflict of Interests: There are no conflicts of interest.

\section{REFERENCES}

Abhijeet AS, Pradeep NA, Dnyanoba MM, Sneha ML, Ankita PJ. Densitometric simultaneous quantification of three naphthoquinones from Impatiens balsamina L. leaves by High-Performance Thin-Layer Chromatography. Journal of Planar Chromatography, 2014; 27: 357-361.

Anonymous. 1959. The Wealth Of India, Raw Materials. Council of Scientific \& Industrial Research, New Delhi. Vol. V, 168.

Archana B, Bratati D. Antioxidant activity of ethnomedicinally

used flowers of West Bengal, India. International Journal of Pharmacognosy and Phyatochemical Research, 2014; 6 (3):622635. 
Baskar N, Parimala DB, Jayakar B. Evaluation of antioxidant activity of ethanol extract of Erythrina variegata and Impatiens balsamina on chromium(VI) induced oxidative stress in Albino rats. Int. Jour. of Res. In Pharmacology and Pharmacotherapeutics, 2012a; 1(1):31-34.

Baskar N, Parimala DB, Jayakar B. Anticancer studies on ethanol extract of Impatiens balsamina. International journal of research in Ayurveda and Pharmacy, 2012b; 3(4):631-633.

Binorkar SV, Jani DK. Profile of medicinal plants with Antiophidian property. Journal of Pharmaceutical and Scientific Innovation, 2012; 1(5): 13-20.

Bohm B A. Naphthoquinone biosynthesis in higher plants, phydroxybenzoic acid as a precursor of 2-hydroxy 1,4-naphthoquinone in Impatiens balsamina. Biochemical and Biophysical Research Communications, 1967; 26(5): 621-624.

Calderon-Montano J M, Burgos-Moron E, Perez-Guerrero C, Lopez-Lazaro M. A review on the dietary flavonoid Kaempferol. MiniReviews in Medicinal Chemistry, 2011; 11: 298-344.

Chang S. 1977. Dictionary of Chinese Crude Drugs. Shanghai Scientific Technologic Publisher: Shanghai.1883.

Chatterjee A, Chandra Pakrashi S. 1997. The Treatise on Indian Medicinal Plants. National Institute of Science Communication, New Delhi. Vol. 3, 134-135.

Chen XM, Qian SH, Feng F. Two new tetrahydronaphthalenes from the stem of Impatiens balsamina L.. Chinese Chemical Letters 21, $2010 ; 440-442$

Chopra RN, Nayar SL, Chopra IC. 1956. Glossary Of Indian Medicinal Plants. Publications \& Information Directorate, CSIR. 140.

Chopra RN, Chopra IC, Varma BS. 1969. Supplement To Glossary Of Indian Medicinal Plants. Publications \& Information Directorate: New Delhi. 45-46.

Clevenger S. The flavonols of Impatiens balsamina $\mathrm{L}$.. Archives of Biochemistry and Biophysics, 1958; 76: 131-138.

Collett H. 1921. Flora Simlensis. Thacker, Spink \& Co.. $2^{\text {nd }}$ Impression. 72-73.

Debashree N, Subhalaksmi A, Rita S, Pfuzia A. Study of analgesic and anti-inflammatory effects of Impatiens balsamina leaves in albino rats. Int J Pharm Bio Sci, 2013; 4(2):581-587.

Ding ZS, Jiang FS, Chen NP, Lv GY, Zhu CG. Isolation and identification of an Anti-tumor Component from leaves of Impatiens balsamina. Molecules, 2008; 13:220-229.

Fukumoto H, Ishiguro K, Murashima T, Yamaki M, Isoi K. Structure determination of a Kaempferol 3-Rhamnosyldiglucoside from Impatiens balsamia. Phytochemistry, 1994; 37(5): 1486-1488.

Herber D. 1864. Hand Book of The Indian Flora. Crabancore Sircar Press. Vol. I, 185-186.

Herrera AA, Ocampo MA, Guevara AP. Histological effects of Impatiens balsamina Linn. crude extract and isolate to 2-methoxy-1,4naphthoquinone on the pancreas, stomach, duodenum and spleen of tumorinduced Mus musculus. Journal of Medicinal Plants Research, 2013; 7 (38):2846-2858.

Hua L, Peng Z, Chia LS, Goh NK, Tan SN. Separation of kaempferols in Impatiens balsamina flowers by capillary electrophoresis with electrochemical detection. Journal of Chromatography A, 2001; 909: 297-303.

Imam MZ, Nahar N, Akter S, Rana MS. Antinociceptive activity of methanol extract of flowers of Impatiens balsamina. Journal of Ethnopharmacology 142, 2012; 804-810.

Ishiguro K, Fukumoto $\mathrm{H}$. A practical and speedy screening method for murine anaphylaxis: On the antianaphylactic effect of Impatiens balsamina L.. Phytother Res, 1997; 11 (1):48-50.

Ishiguro K, Fukumoto H, Murashima T, Kuriyama M, Semma M, Isoi K. Antianaphylactic effects of the ethanolic extract from the petals of Impatiens balsamina L. in mice. Phytother. Res., 1992; 6(2):112-113.

Ishiguro K, Ohira Y, Oku H. Antipruritic Dinaphthofuran-7,12dione derivatives from the pericarp of Impatiens balsamina. J. Nat. Prod., 1998; 61(9): 1126-1129.

Ishiguro K, Ohira Y, Oku H. Preventive effects of Impatiens balsamina on the hen egg-white lysozyme (HEL)-induced decrease in blood flow. Biol Pharm Bull, 2002; 25 (4):505-508
Ishiguro $\mathrm{K}, \mathrm{Oku} \mathrm{H}$, Kato T. Testosterone 5alpha-reductase inhibitor bisnaphthoquinone derivative from Impatiens balsamina. Phytotherapy research., 2000; 14:54-56.

Jain B. Antimicrobial activity of seed extract of Impatiens balsamina Linn. Current World Environment, 2011; 6(2): 299300.

Jalalpure SS, Alagawadi KR, Mahajanashetti CS, Shah BN, Salahuddin, Singh V, Patil J K. In vitro anthelmintic property of various seed oils against Pheritima posthuma. Indian journal of pharmaceutical sciences, 2007; 69 (1):158-160.

Jaykrishna IT. 1998. Vanaspati Shashtra. Pravin Prakashan Pvt. Ltd: Rajkot. 123-124.

Jin B, Song ZC, Jiang FS, Liu WH, Ding ZS. 2Methoxynaphthalene-1,4-dione. Acta Cryst., 2011; 67: 0947.

Jing L, Shi HQ, Jian QJ. Two new flavones glycosides from the seeds of Impatiens balsamina L.. Journal of Asian Natural Products Research, 2010; 12 (12): 1033-1037.

John SA, Koperuncholan M. Antibacterial activities of various solvent extracts from Impatiens balsamina. International Journal of Pharma and Bio Sciences, 2013; 3(2): 401-406.

Kang SC, Moon YH. Isolation and antimicrobial activity of a naphthoquinone from Impatiens balsamina. Saengyak Hakhoechi, 1992; 23: $240-247$

Kang SN, Goo YM, Yang MR, Ibrahim RIH, Cho JH, Kim IS, Lee $\mathrm{OH}$. Antioxidant and antimicrobial activities of ethanol extract from the stem and leaf of Impatiens balsamina L. (Balsaminaceae) at different harvest times. Molecules, 2013; 18: 6356-6365.

Kirtikar KR, Basu BD. 1933. Indian Medicinal Plants. New Cinnaught Place, Dehra Dun. Vol. I, 445-446.

Lim YH. Tyrosinase inhibitor from the flowers of Impatiens balsamina. Journal of Microbiology and Biotechnology, 2006; 16(12):1977-1983.

Lim YH, Kim IH, Seo JJ. In vitro activity of Kaempferol isolated from the Impatiens balsamina alone and in combination with Erythromycin or Clindamycin against Propionibacterium acnes. The Journal of Microbiology, 2007; 45(5):473-477.

Madhav R. 1959. Glimpses of Nature, Our Monsoon Plants. Bombay Natural History Society. Series no. 4, 7 .

Mishra RK, Patel SP, Srivastava A, Vashistha RK, Singh A, Puskar AK. Ethnomedicinally important plants of Panchmarhi region, Madhya Pradesh, India. Nature and Science, 2012; 10(4): 22-26.

Nadkarni KM. 1989. Indian Materia Medica. $3^{\text {rd }}$ Edition. Popular Prakashan : Bombay. Vol.I. 676.

$\mathrm{Oku} \mathrm{H}$, Ishiguro K. Screening method for PAF antagonist substances: on phenolic compounds from Immpatiens balsamina $\mathrm{L}$. Phytother Res, 1999; 13 (6):521-525.

Oku H, Ishiguro K. Antipruritic and antidermatitic effects of extract and compounds of Impatiens balsamina L. in atopic dermatitis model NC mice. Phytother. Res., 2001; 15(6):506-510.

$\mathrm{Oku} \mathrm{H}$, Ishiguro K. Cyclooxygenase-2 inhibitory 1,4naphthoquinones from Impatiens balsamina L.. Biol Pharm Bull, 2002; 25 (5):658-660.

Ong HC, Zuki RM, Milow P. Traditional knowledge of medicinal plants among the malay villagers in Kampung Mak Kemas, Terengganu, Malaysia. Ethno Med, 2011: 5(3):175-185.

Panichayupakaranant P, Noguchi H, De-Eknamkul W, Sankawa U. Naphthoquinones and coumarins from Impatiens balsamina root cultures. Phytochemistry, 1995; 40(4): 1141-1143.

Panichayupakaranant P, Noguchi H, De-Eknamkul W. A new biscoumarin from Impatiens balsamina root cultures. Planta med, 1998; 64(8): 774-775.

Patra A, Chaudhari SK. Chemical constituents of Impatiens balsamina Linn. Journal of the Indian Chemical society, 1988; 65: 367 368.

Pei H, Lei J, Qian S H. A new cytotoxic dinaphthofuran-7,12dione derivatives from the seeds of Impatiens balsamina. Journal of Chinese medicinal materials, 2012; 35 (3):407-410.

Rajendra R, Manikandan A, Hemalatha K, Mary SM, Prabhavathi P. Antimicrobial activity of Impatiens balsamina plant 
extract. World Journal of Pharmacy and Pharmaceutical Sciences, 2014; 3 (7):1280-1286.

Rastogi RP. 1970-1979. Compedium Of Indian Medicinal Plants. Publications \& Information Directorate: CDRI. Vol. 2. 386.

Rastogi RP. 1985-1989. Compedium Of Indian Medicinal Plants. Publications \& Information Directorate: CDRI. Vol. 4. 398.

Rastogi RP. 1990-1994. Compedium Of Indian Medicinal Plants. Publications \& Information Directorate: CDRI. Vol. 5. 447.

Sakunphueak A, Panichayupakaranant P. Simultaneous determination of three naphthopuinones in the leaves of Impatiens balsamina L. by reversed-phase High-performance Liquid Chromatography. Phytochemical analysis, 2010; 21: 444-450.

Sakunphueak A, Panichayupakaranant P. Comparision of antimicrobial activities of naphthoquinones from Impatiens balsamina. Natural Product Research, 2012; 26(12): 1119-1124.

Sanghi DK and Tiwle R, Herbal drug and excipient used in cosmetic preparation for the enhancement of beauty, Int. J. Med. Pharm. Res., 2013, 1(3), 308-317.

Sha L, Shu-Ke L, Ren-You G, Feng-Lin S, Lei K, Hua-Bin L. Antioxidant capacities and total phenolic contents of infusions from 223 medicinal plants. Indistrial Crops and Products, 2013; 51:289 298.

Shivaji B, Shivakumara, Seitajit SW, Naveen KR, Swarnava K, Siddharth D, Vedamurthy AB. Phytochemical screening and biological activities of Impatiens balsamina L seeds. World Journal of Pharmacy and Pharmaceutical Sciences, 2013; 2 (6):5363-5376.

Shoji N, Umeyama A, Saitou N, Yoshikawa K, Kan Y, Arihara S. Hosenkosides A, B, C, D and E, novel Baccharane glycosides from the seeds of Impatiens balsamina. Tetrahedron, 1994(a); 50: 49734986

Shoji N, Umeyama A, Taira Z, Takemoto T, Nomoto K, Nizukawa K, Ohizumi Y. Chemical structure of hosenkol-A, the first example of the natural baccharane triterpenoid of the missing intermediate to shionane and lupine. Journal of the chemical society, Chemical communications, $1983 ; 16$ : 871-873.

Shoji N, Umeyama A, Yoshikawa K, Nagai M, Arihara S. Baccharane glycosides from seeds of Impatiens balsamina. Phyatochemistry, 1994(b); 37 (5): 1437-1441.

Srivastava A, Patel SP, Mishra RK, Vashistha RK, Singh A, Puskar AK. Ethnomedicinal importance of the plants of Amarkantak region, Madhya Pradesh, India. Int. J. Med. Arom. Plants, 2012; 2(1): $53-$ 59.
Tailor RH, Acland DP, Attenborough S, Cammue BP, Evans IJ, Osborn RW, Ray JA, Rees SB, Broekaert WF. A novel family of small cysteine-rich antimicrobial peptides from seed of Impatiens balsamina is derived from a single precursor protein. J Biol Chem, 1997; 26, 272 (39):24480-87.

Thevissen K, Francosis IE, Sijtsma L, Amerongen AV, Schaaper WM, Melown R, Trumpie TP, Broekaert WF, Cammue BP. Antifungal activity of synthetic peptides derived from Impatiens balsamina antimicrobial peptides Ib-AMP1 and Ib-AMP4. Peptides, 2005; 26:1113-1119.

Uniyal B, Shiva V. Traditional knowledge on medicinal plants among rural women of the Garhwal Himalaya, Uttaranchal. Indian J of Traditional Knowledge, 2005; 4(3): 259-266.

Wang P, Bang JK, Kim HJ, Kim JK, Kim Y, Shin SY. Antimicrobial specificity and mechanism of action of disulfide-removed linear analogs of the plant-derived Cys-rich antimicrobial peptide IbAMP1. Peptides, 2009; 30:2144-2149.

Wang YC. In vitro activity of Impatiens balsamina $\mathrm{L}$. against multiple antibiotic-resistant Helicobacter pylori. Am. J. Chin. Med., 2009 37(4):713-722.

Wang YC, Li WY, Wu DC, Wang JJ, Wu CH, Liao JJ, Lin C K. In vitro activity of 2-methoxy-1,4-naphthoquinone and stigmasta-7,22diene-3 $\beta$-ol from Impatiens balsamina $\mathrm{L}$. against multiple antibioticresistant Helicobacter Pylori. Evidence-Based Complementary and Alternative Medicine,2009;1-8.

Wang YC, Lin YH. Anti-gastric adenocarcinoma activity of 2Methoxy-1,4-naphthoquinone, an anti-Helicobacter pylori compound from Impatiens balsamina L.. Fitoterapia, 2012; 83:1336-1344.

Yang X, Summerhurst DK, Koval SF, Ficker C, Smith ML, Bernards M A. Isolation of an Antimicrobial compound from Impatiens balsamina L. using bioassay-guided fractionation. Phytotherapy Research, 2001; 15:676-680.

\section{How to cite this article:}

Shah KN, Verma P, Suhagia B. A phyto-pharmacological overview on Jewel Weed. J App Pharm Sci, 2017; 7 (08): 246-252. 